\title{
9
}

\section{Censorship and the institution of knowledge in Bacon's New Atlantis}

\author{
SIMON WORTHAM
}

I

Critical readers of Bacon's New Atlantis have often drawn attention to the complex relationship between, on the one hand, the production and dissemination of enlightened scientific knowledge in Bensalem - and, indeed, the forms of social community for which it implicitly provides a model - and, on the other, the secret or concealed conditions of this very same process of production. For example, Robert K. Faulkner in Francis Bacon and the Project of Progress notes that, while 'every official performs his function [and] everyone does what he is ordered,' nevertheless 'all this order is the more remarkable since the relation of king, city, nation, state, and scientist is not clarified. The order that orders ... is hidden. ${ }^{\prime}$ Jerry Weinberger, meanwhile, argues that Bensalemite 'science is shrouded in secrecy, denying the possibility of full enlightenment.' Such secrecy surrounding the activities which contribute to the production of scientific knowledge Weinberger reads in terms of, as he sees it, Bacon's idea that 'the politics of science must be secret and retired because only the most resolute souls will be willing to embrace such a world with full knowledge of its moral risks and dangers. ${ }^{2}$ What these critics would appear to suggest, then, is that the production of various sorts of ground-breaking scientific knowledge and enlightened social relationships remain dependent, at bottom, upon a supplementary dose of censorship that simply cannot be dispensed 
with if the project of the Bensalemites is to persist and thrive. For readers of Bacon and students of the early modern period in England more generally, the New Atlantis therefore unavoidably raises questions concerning the relationship between censorship and knowledge, insofar as this relationship actually comes to structure and define the possibilities for any advancement of learning of the sort that is imagined to take place in the formal, institutional space of an ideal academy such as Salomon's House.

One of the places where questions of censorship have been raised most interestingly in recent times is in Renaissance studies. For example, Richard Burt, in his book Licensed by Authority: Ben Jonson and the Discourses of Censorship, ${ }^{3}$ has attempted to rethink the problem of censorship in the early modern period in ways that call into question some of the conceptions and assumptions concerning censorship that have typically underpinned supposedly more 'radical' critiques of the workings of power and authority in sixteenth- and early seventeenth-century England. In particular, Burt describes an 'ahistorical, moral definition of censorship' (censorship as a repressive, external threat to essential freedoms) that has been adopted by 'political critics' working on the early modern period (particularly British cultural materialists), which 'makes available in the Renaissance a certain essentially moral notion of critical opposition'. 'By extension,' argues Burt, 'a similar kind of critical opposition becomes available in the present.' ${ }^{4}$ This situation may well have come about, as Robert Young has noted, because cultural materialism as a broadly leftist critical practice has pretty much supplanted or displaced the dialectical or 'historical' materialism it inherits, such that 'a form of reflection theory' has been reasserted, through which 'history has become a mirror in which contemporary political priorities have been substituted for the former certain ground of Marxist analysis. ${ }^{5}$ By extension of his or her reading of the Renaissance in terms of 'moral' definitions of censorship, then, Burt goes on to contend that the political critic 'can be seen to oppose at once the professionalism and the formalism of a supposedly apolitical literary criticism and the postmodern (now post-Reaganite and post-Thatcherite) state. Thus censorship and criticism become self-identical terms that can be juxtaposed in a stable opposition; the critic is "opposed" to censorship.' 
Of course, cultural materialists must oppose and expose, too, reactionary standpoints on Renaissance literature and culture by showing them to be politically motivated, thus revealing their ostensible apoliticism as an ideological smokescreen. As the foreword to Political Shakespeare puts it, cultural materialism 'does not, like much established literary criticism, attempt to mystify its perspective as the natural, obvious or right interpretation of an allegedly given textual fact'. ${ }^{7}$ Yet to distinguish itself from these positions, political criticism has often been forced to repeat the mystificatory stance of truth, reference and legality (note the legalistic tone of 'allegedly') which it typically criticises in its opponents. Thus, in order to contest Nigel Lawson's conservative reading of Troilus, for example, Margot Heinemann, in Political Shakespeare, argues that the ex-Chancellor presents his quotations 'wholly out of dramatic context' which she then goes on properly to retrieve. ${ }^{8}$ As Robert Young puts it, this kind of manoeuvre in fact attempts to 'reground the link between representation and reference that has been questioned by the semiotics of the last twenty [now more than thirty] years' ${ }^{9}$ In suggesting that her position is more 'true' to its object (and her understanding of a dramatic excerpt more 'true' to its context) than is Lawson's, Heinemann produces a mystificatory reading, 'the right interpretation of an allegedly given textual fact'. Similarly, Walter Cohen in his essay 'Political criticism of Shakespeare' stresses the demythologising power of political criticism, but then becomes trapped in a position where he is compelled to insist that the leftwing 'partisanship' of contemporary 'political writing on Shakespeare' is 'not only compatible with but also necessary to a commitment to objectivity and scholarship'. ${ }^{\text {10 }}$ This in fact realigns radical critique with oppressive ideology, which tries to represent its politics, 'partisanship', as 'true'. Cohen's backsliding into 'objectivity and scholarship' signals at once a retreat from reactionary 'false politics' and a return to the politically disinterested, judicial image of the intellectual on which, according to cultural materialism, those politics are founded. It is indeed within the very process of differentiation between two opposable 'positions' that an uncanny identity emerges. Thus, censorship (or rightwing 'misreading') and (leftist) criticism cannot, to borrow Burt's language, be 'juxtaposed in a stable opposition', since 'political' 
criticism can often only legitimate and sustain itself as radically oppositional (or, as it were, 'free') by way of a forceful repression of its own 'politics' or, in other words, by censorship of itself.

Burt's Licensed by Authority argues against any clear-cut distinction between criticism and censorship, poetic liberty and licensed poetry, within the multiple and dispersed, and often equivocal and contradictory, spaces and conditions of the court and market during the early seventeenth century. Here, following Bourdieu's sense that the acquisition and formation of cultural capital (the market) depends on 'a compromise between the expressive interest and a censorship constituted by the very structure of the field in which discourse is produced', ${ }^{\text {II }}$ Burt argues that Renaissance panegyric 'involves neither willing submission to courtly tact nor open defiance of it but a mixture of both ... a neurotic compromise between the desire to fit in and the desire to express the censored material'. ${ }^{12}$

Such broadened and non-oppositional conceptions of censorship, in which the 'negative, repressive function is ... only one of the many regulatory mechanisms' ${ }^{1}{ }^{13}$ and of criticism, which can be seen to legitimate as well as delegitimate both the writer and the court, are by no means exclusive to Burt's book. Richard Dutton's Mastering the Revels, for example, concludes that 'the position of the Master of the Revels, jealously protecting court privileges as much as he sought to suppress "dangerous matter", made him as much a friend of the actors as their overlord. The stability that his office gave to an exchange of meaning in the early modern theatrical market-place clearly played a part in fostering the unique vitality of the drama of the period'. ${ }^{4}$ Annabel Patterson similarly emphasises this 'productive' aspect of censorship, noting that it is to censorship that we in part owe our very concept of "literature" "; ${ }^{15}$ while others such as Janet Clare, Kevin Sharpe and Steven Mullaney have contributed to an ongoing and lively reconsideration of the complex interplay between censorship and licence insofar as it concerns the field of Renaissance studies. ${ }^{16}$ Such studies provide a useful context in which to return, with questions of knowledge and censorship in mind, to Bacon's New Atlantis.

Before so doing, and given that a discussion of some contemporary critical trends and debates has been taken to frame an 
approach to Bacon's text, it is perhaps worth making a - necessarily very brief - comment on the question of historical difference and relationship that inevitably surrounds any such project of re-reading. While it is important not to repeat the kind of 'reflectionism' that Robert Young associates with some cultural materialist strategies of reading, whereby the past functions rather straightforwardly as a platform for larger arguments of topical relevance, nevertheless it seems to me equally problematic to position the New Atlantis historically according to crude notions of epoch or chronological pastness, since such ostensibly stable conceptions of time (and indeed place) are themselves rendered uncertain in the text by the uncanny relation of Bensalem to Europe and, by extension, to the values of progress and linearity that begin to emerge on the cusp (or on just the other side) of Enlightenment. This uncanny relationship upsets the designation of a self-identical point of origin or ground on which rest traditional notions of historical time and historical difference (themselves allied to those nascent Enlightenment values). However, as a text that is in many ways in flux, in transition or in some other sense 'at sea', the New Atlantis may be of interest to the contemporary reader in that it seems possible to locate Bacon's text within the interstitial space of a shift from 'premodern' to 'modern' types of legitimation, a shift that Lyotard discusses extensively in his account of the postmodern condition. In Lyotard: Writing the Event, Geoffrey Bennington states that 'Lyotard suggests a change from a sort of classical and premodern science which produced narratives for seeking legitimisation in an origin or ground, a first principle or a transcendental authority, to "modern" forms of legitimation based on consensus ... [this] type of legitimation allows for the possibility that the discussion of experts can lead to an improvement in the rules for speaking truth, and that this improvement can be projected into a future under the sign of progress.' ${ }^{17}$ This transitional phase resonates with the shift from deduction to induction, from similitude to Cartesian separation and classification, from sameness to difference, that can be located at the horizon of the early modern period and, more particularly, identified with Bacon himself. Reading (and locating historically) the New Atlantis in the interstices of these forms of legitimation, in a space of contestation and struggle 
between the authority of a ground and the concerns of the present with its politics of future use-value, it is not surprising that the text itself raises questions of historical method, taking us beyond simple 'either/or' choices of sameness/difference.

\section{II}

According to Rawley, Bacon's secretary, the 'fable' of the New Atlantis $^{18}$ was devised by its author so as to 'exhibit therein a model or description of a college instituted for the interpreting of nature and the producing of great and marvellous works for the benefit of men, under the name of Salomon's House' (36). Salomon's House exemplifies in ideal terms the advancement of learning, in the context both of academic principle and institutional practice. As B. H. G. Wormald has put it, as well as providing 'a framework of directing axioms conducive to learning's advancement', the New Atlantis is Bacon's 'vision of an institution established by government for furthering natural philosophy/science' ${ }^{19}$ As a source of enlightenment, discovery and invention, Salomon's House is, to borrow Burt's phrase, licensed by authority: it is created and officially sanctioned by royal act (58); and the Father of Salomon's House, who imparts to the European visitors 'the true state' - the foundations, instruments, functions and ordinances - of the institution, is himself described as arriving, almost regally, 'in state' (69). The close connections between the state and the academy are underlined, then, through reference to the authority of the House of Salomon's officials; but also the authority of the institution is reflected in the orderliness that everywhere characterises its activities. As a research institute, it supports the study of, among other things, the natural sciences, mathematics and geometry, philosophy, medicine, the mechanical arts, and optics and acoustics. The description offered by the Father of the means and ends of these pursuits is given in terms of an extremely lengthy and well-ordered identificatory and classificatory grouping and listing of the various faculties and functions within the academy, bordering on the facile, so that the almost legalistic monologism of the Father's speech can be taken to reflect the legality as well as the orderliness of the institution. Indeed, since it tells us so little that might really be interesting 
(about scientific ethics, for example, or the precise terms of the relationship between state and academy) the Father's account of the 'true state' of Salomon's House is characterised by an absence of interlinearity to which, we might imagine, all censors aspire, alerting us to the possibility that the revelation to which we are brought in the concluding section of the New Atlantis may be communicated in the very language of censorship.

The orderliness of the institution's academic disciplines is matched by that of the conduct of its officials. As we have already seen, Robert K. Faulkner remarks that 'every official performs his function [and] everyone does what he is ordered'. However, as he goes on to point out, 'all this order is the more remarkable since the relation of king, city, nation, state, and scientist is not clarified. The order that orders ... is hidden' ${ }^{20}{ }^{20}$ It is generally recognised that this utopian domain of enlightened knowledge, declaring itself dedicated to 'Light: to have light' (59), is founded upon such concealment, although critics disagree as to exactly what is being concealed. Recall how Jerry Weinberger notes that Bensalemite 'science is shrouded in secrecy, denying the possibility of full enlightenment', attributing this to Bacon's sense that 'the politics of science must be secret and retired because only the most resolute souls will be willing to embrace such a world with full knowledge of its moral risks and dangers. ${ }^{21}$ From this point of view, any consideration of the ethical implications and responsibilities of science and learning must therefore be censored in order for enlightenment, advancement and progress to continue apace. In contrast, Faulkner reads the New Atlantis in the context of what he sees as Bacon's belief that the 'science of government is a thing secret and reserved, to be handled with reverence and even in silence.' ${ }^{22}$ According to this analysis, it is the governing social and material contexts and conditions rather than the moral implications of the academy's activities that must remain invisible: a different sort of politics of science. This is backed up by Faulkner's contention that the very processes of production underlying the achievements of Salomon's House and Bensalem generally are concealed. He states, 'we are plied with a promise of pleasant affluence, but any system of painful industry and production is kept well behind the scenes' ${ }^{23}$ Indeed, the catalogue offered by the Father of Salomon's House 
of its faculties and functions barely touches upon the labours of production involved (we are occasionally told what is done, but rarely how it is done), so that science and knowledge are described, as it were, within the rhetorical terms of commodity fetishism, in which the means to the end are hidden from view.

This difficulty of saying exactly what is concealed in the New Atlantis, either at the social or textual level, arises partly out of the problem of identifying something that is not, in any apparent way, there. Absence can, of course, be defined simply in an oppositional relationship to presence, but (as we shall see in the New Atlantis) what is present is itself a matter of interpretation or reading, and, as such, cross-cut by effects of uncertainty, ambiguity or a certain sort of slipperiness. Thus, the identificatory strategies of an oppositional logic of presence/absence are undermined by the 'otherness' or internal difference of what is present. Indeed, Bensalem, as both an exemplary 'model' and a 'secret conclave' (5I) exists, in Freudian terms, in an uncanny relation to the positivistic knowledge, progress and plenitude that gains importance on the way to a nascent European-Enlightenment project, representing simultaneously 'what is familiar and agreeable' and 'what is concealed and kept out of sight'. ${ }^{24}$ In these terms, the polarities and boundaries of known/unknown, visible/ invisible, outside/inside collapse into more complex and undecidable formations epitomised by the non-self-identical doubleness of Europe/Bensalem. The New Atlantis is both a beacon of previously undiscovered wisdom and truth and, as Bacon puts it, 'a mirror in the world worthy to hold men's eyes' (6o): both subject and object, self and other.

Thus, it would seem that critics and readers of the New Atlantis are placed in the same boat as the European visitors themselves. That is, these critics become, as it were, knowledgeably ignorant, just as the European voyagers become, as it were, ignorantly knowledgeable, of Bensalemite learning and society. The journey of the Europeans towards revelation, like that of the critic towards understanding, is beset at every turn - even, as we have seen, at the end - by limitations, confinements and prohibitions, as if such constraints were less an obstacle to than a condition of enlightenment. A host of terms are laid down before the strangers can come ashore, including the restriction of numbers allowed to 
enter Bensalem, and the taking of an oath prior to the 'license to come on land' (40). They are 'sent to, and brought to the Stranger's House' (4I) or, in other words, escorted along predetermined routes. They are subjected to an initial period of quarantine in 'chambers' and 'cells' in which are continually present 'six people appointed to attend you, for any business you may have abroad' (42). Whether or not these officials are intermediaries or guards, their job is clearly to forcibly prevent contaminatory contact between the Bensalemites and the Europeans. Here, we find that the utopian space of enlightenment is a protected and protective zone, quick to enforce its borders against real and symbolic threats of infection. However, the brick walls that keep the strangers in are also presented as a means of ensuring undisturbed freedom. They are assured, 'do not think yourselves restrained, but rather left to your rest and ease' (42), and subsequently spend 'three days joyfully and without care' (44). In this sense, the boundary that materially divides the Europeans and the Bensalemites is itself symbolically subverted and transgressed the moment it is enforced, since the freedoms of both are guaranteed by the prohibitory borders of both, opening out the suggestion of an identity or parallel state that contradicts images of hermetically closed non-contact and difference.

It is worth looking more closely at the way in which the enlightenment offered by the Bensalemites is, as Weinberger puts it, 'shrouded in secrecy'.${ }^{25}$ Revelation is made in the rather conspiratorial manner of exclusive, private conversations. The officer of Salomon's House encountered initially by the Europeans desires, we are told, 'to speak with some few of us, whereupon only six of us stayed, and the rest avoided the room' (44). The interview with the Father of Salomon's House is described in terms of 'private access' and 'private conference with one that ye shall choose'; and, prior to his disclosure, all other company departs and even the pages are 'warned' from the room (70-I). Moreover, the special privilege of revealed wisdom is highlighted by reference to 'the laws of secrecy which we have for our travellers' (46) and through the affirmation that Bensalem is founded on 'fundamental laws' comprising 'interdicts and prohibitions which we have touching the entrance of strangers'. Furthermore, just as things start to get interesting, the speaker is 
invariably called away rather abruptly by a mysterious messenger $(49,68)$. Some critics have interpreted these interruptions as evidence of Bensalemite surveillance and self-censorship, ${ }^{26}$ yet they do not seem to inhibit, at a later stage, further scenes of revelation which dynamise and propel the structure of the narrative itself. Flying in the face of critical assertions that Bensalemite secrecy masks the organising principles and infrastructural pith of their society, these shenanigans (the orchestration of private conversations, the sense of exclusive revelation, even of clandestine liaison) might therefore appear to be little more than an elaborate way of convincing the strangers that Bensalemites have juicy secrets to share! From this point of view, Bensalemite secrecy does not constitute a form of repression operating at the threshold of enlightenment, but enacts a kind of 'productive' censorship, in which the controlled management and manipulation of what is apparently unsaid and unrevealed lends meaning, value and authority to what is said and discovered. Correspondingly, from this perspective, we move from Faulkner's contention that 'the order that orders ... is hidden' (repression) to Lyotard's 'problematic of legitimation' of modern science, in which the non-transcendental legality of the law problematises dreams of unearthing ultimate proofs of prior truths, but also prompts enlightenment fantasies of improvement, development, progress, under the sign of a future (production). ${ }^{27}$

On beginning the instruction of the strangers, the officer of Salomon's House states that there are 'some things I may tell you, which I think you will not be unwilling to hear' (44). The commencement of Bensalemite disclosure is couched in delightfully interlinear terms: reading between the lines, the implication is, of course, that there are other things that may not be told, and which in any case the Europeans would be unwilling to hear. Weinberger argues that the subject of this 'unsaid' is itself prohibitory restraint: 'if Bensalemite law and policy are consistent, strangers unwilling to stay, or those judged unfit to stay, must have been restrained by force or killed. This doubtless the sailors would not have been willing to hear. ${ }^{28}$ However, the idea that the officer's speech censors (or is censored) is not consistent with the interlinearity of the phrasing found here. The sophisticated twists and turns of syntax produce, as Paul de Man has put it, 
'negative knowledge about the reliability of linguistic utterances', ${ }^{29}$ encouraging interrogative reading. Thus, the censorship found by Weinberger in the official's statement actually produces a kind of enlightenment. Although it is possible to read into the official's remarks a sinister and foreboding sense of limitation, we can also interpret what he says as an act of enticement rather than prohibition - though no less disingenuous, perhaps - urging the listener to believe that there is more to know beyond the threshold of what is said, and thus sustaining the very project of enlightenment.

At another point, the officer says 'because he that knoweth least is fittest to ask questions, it is more reason, for the entertainment of the time, that ye ask me questions, than that I ask you' (46). This proposition might immediately raise suspicion: 'ask me anything you like' isn't the same as 'I'll tell you everything I know.' Indeed, granting the freedom to ask ingeniously shifts the onus from the expert official to the unknowledgeable questioner, to the extent that it may be seen to provide an ideal opportunity to neglect a mass of information. This leaves the Europeans no grounds for complaint about suppression since no prior limitations have been placed on the questioning. Yet it is precisely the absence of these limitations, in the sense of a fixed context of discussion, that limits what will become known. Reading between the lines, it seems that - within the particular formation of enlightenment found here - limits and parameters are an essential precondition if knowledge is to be optimised. From another perspective, however, the idea of an almost bottomless pit of hitherto undiscovered knowledge responsive to any question whatsoever (although attainable only by the fixing of contextualising limits) encourages the unknown to be sifted ad infinitum; so that once again it is indispensably within the context of boundaries (known/unknown, visible/invisible, inside/ outside), albeit the crossing and relocating of them, that we find the enabling conditions of the enlightenment project.

\section{III}

The problem of enlightenment in the New Atlantis rests, then, on whether truth is or can be divined in a prior relation to knowledge, 
or whether knowledge - as a complex formation of linguistic encounters and propositions - represents truth into being. We are told early on that Bensalem has been founded on Christian revelation. A mile out to sea, a 'great pillar of light' topped by a 'large cross of light' appears 'about twenty years after the ascension of our Saviour' to the 'people of the city'. For a while, this revelation remains shrouded in mystery, as the sign conveys no message as such. However, one of the wise men of the society of Salomon's House is at hand and, 'having awhile attentively and devoutly viewed and contemplated the pillar and cross', he prays to God that interpretation will be forthcoming. While all others remain miraculously transfixed, the wise man alone is permitted to approach the pillar of light, and delivered to him is an 'arc or chest' in which is found a 'book' containing 'all the canonical books of the Old and New Testament' as well as a 'Letter' bringing the good news of salvation from St Bartholomew (47-8). This scene lies at the origins of a symbolic interplay which runs throughout the New Atlantis, between the spiritual 'light' of Christianity and the project of enlightenment founded by the House of Salomon, suggesting that its advancement of learning is divinely sanctioned and illuminates a transcendental signified. Thus, unsurprisingly, the wondrous meaning of the 'great pillar of light' becomes apparent foremost to the 'house or college' (in the shape of the representative figure of the wise man) which is 'the very eye of this kingdom' (48).

However, the relation between Christian 'light' and scientific enlightenment becomes problematic at the very moment the analogy between the two hardens. A few pages later, we are told that Salomon's House is itself the 'lanthorn' or light of Bensalem (58). It is not simply that this doubling and displacement of the source of illumination might appear heretical. More importantly, the 'eye' that sees is itself the 'light' that illuminates. In what Christopher Pye describes as the 'Renaissance theory of sight beams', ${ }^{30}$ the eye is the agent of what it perceives, and indeed in the pageant poetry written to celebrate James I's accession, the king himself is represented simultaneously as the ultimate source of light, a sun, and a self-illuminating, all-seeing eye. ${ }^{3 \mathrm{I}}$ The currency of such contemporary ideas can be traced elsewhere in the New Atlantis. Although we are told that Bensalem is a 
copious source of 'light', it remains 'hidden and unseen to others', while the less enlightened Old World is nevertheless 'open and in a light' to Bensalemite travellers (5I). This apparent reversal of the scenes of illumination and darkness in fact attributes the presence or absence of 'light' to the subject rather than the object, the seeing eye rather than the thing viewed. Such configurations seem to align more with Bacon's views on poetry than with his views on science. Quoting from The Advancement of Learning, Faulkner states: 'According to Bacon ... poetry is ... a rational management of invented illusion to help satisfy real desire. Poets do not divine an ideal or feel the sublime. They incline to "submit the shows of things to the desires of the mind"'.32 The emphasis within Bacon's concept of poetic vision on subjectivity and sense-impression clearly foreshadows certain strands of eighteenth-century philosophical discourse, but most interestingly this view of poetry as the conscious manipulation of consciousness advocates rationalism without recourse to pre-existing 'truth'. Poetry's self-reflexivity seems, however, to be present in Bensalemite science: Salomon's House is both the eye that sees and the light that illuminates. Indeed, it is possible to re-read the scene of Christian revelation in the New Atlantis in light of Bacon's conception of poetic vision: that is, in aligning Christianity and science as compatible belief systems or narratives and thus satisfying spiritual and secular needs simultaneously, the spectacle serves to 'submit the shows of things to the desires of the mind'. Thus, Faulkner casts doubt on the miraculous pillar of light, drawing attention to the theatrical staginess of the scene of revelation (we are told 'the boats stood all as in a theatre' (47)), and noting, in the Father's description of Salomon's House, 'the scientist's ability "to represent all manner of reflections, refractions, and multiplications of visual beams of objects," and to represent also all manner of "false apparitions, impostures and illusions"'. ${ }^{33}$ Indeed, the Father reveals that the Bensalemite science of optics has enabled its proponents to produce artificially 'all delusions and deceits of the sight in figures' as well as unnaturally vivid views of 'objects far off; as in the heaven and remote places'. 'We make artificial rain-bows, halos, and circles of light', he goes on, before concluding with a description of the 'houses of deceits of the senses' within Salomon's 
House itself (78-80). We can only conclude from this irony that, as Faulkner puts it, 'Bacon thinks divinations but artificial light, imaginings like all suppositions of divinity.' 34 Thus, it is not that Salomon's House provides an exemplary, model college in which natural or divine phenomena might be discovered and exhibited; rather, revelation is, in Bourdieu's terms, 'the very structure of the field' in which the 'rational management of invented illusion' can take place so as to 'satisfy real desire', either that of the Bensalemites or the Europeans. And, of course, 'the very structure of the field in which discourse is produced and circulated' constitutes Bourdieu's definition of censorship. Here, however, we are alerted by the fact that it simultaneously constitutes a definition of enlightenment.

\section{IV}

Since, as Faulkner puts it, divination in fact represents the 'rational management of invented illusion', 35 it follows that censorship, as the 'structure of the field' in which it takes place, is enacted non-repressively, as it were, on disclosures that have no primordial unity or transcendental grounding. The revelation of the 'Book' that accompanies the miraculous 'light' of Christianity is, however, presented as being instantaneously and transcendentally complete. It contains not only the portions of the Bible written by AD 20 but also 'some other books which were not at that time written', yet which are 'nevertheless in the Book' (49). In Faulkner's terms, the productive process - the labour and temporality of writing - once again appears to have been concealed or repressed, within the fetishised spectacle of a spontaneous text, both unique and fully finished. From this kind of perspective, the wholeness of the Book is itself a product of repressive exclusions.

As if to confirm the unity of the Book, its reception is characterised by the absence of interlinearity, since by 'a great miracle' similar to 'that of the Apostles in the original Gift of Tongues' the various peoples of Bensalem - 'Hebrews, Persians and Indians, besides the natives' - are all able to read the Book and Letter 'as if they had been written in his own language' (49). This constitutes a kind of reverse Babel-effect in which cultural, religious and 
linguistic fragmentation is miraculously overcome and restored within a monological moment of absolute certainty and harmony. What would appear to be a reclamation of a prior wholeness, both of the text and of the people, is achieved, then, at the expense of any slippage between the lines. Translational ambiguity is entirely dispensed with: just as the productive processes of writing are omitted, so the labour of translation is also redundant and, indeed, even the effort of reading seems to be discounted, since the meaning of the text becomes instantly and unequivocally apparent to all present. This absence of interlinearity suggests, once again, a definition of censorship. But here we find censorship - within the terms of a repressive hypothesis, the harbinger of violence and danger to the project of enlightenment - (co)operating at the very moment of overcoming a castrating severance or fragmentation of the Word and the Nation. The damage done to a repressive hypothesis by this paradoxical state of affairs is compounded, since such censorship cannot be said to excise or suppress an earlier or more complete original: the Book we are dealing with is the ultimate prior text, or otherwise it is part of the 'invented illusion' brought into being by the event itself. Here, denied the lag or gap that it requires between a primary and secondary 'object', this theory of repression runs into trouble: the originality of the Book, its unfaltering continuity with the moment, its non-concealment of anything, is indisputable either way and yet, paradoxically, it is subjected to a kind of censorship. This forces us once again to rethink conventional notions of censorship as blemish, and therefore, by extension, paradoxically unsettles an oppositional image of knowledge as purity at the very moment it would seem, superficially at least, to confirm it.

Both the text and the society of the New Atlantis seem to revolve around the production and circulation of 'little scrolls of parchment' (38) which, embodying the authority of the ChristianBensalemite order, continually reinvoke the scene of revelation of the Book and the Letter. On their first encounter with the Bensalemites, the Europeans are not spoken to, but read to from such a scroll, 'written in Hebrew, and in ancient Greek, and in good Latin of the School'; that is, in universally legible language, not unlike the miraculous Book itself. However, the scroll 
welcomes or 'includes' only to 'prohibit' and exclude its audience: 'Land ye not, none of you' it commands (38). Content and context are here antagonistically fused, as the prohibitory message is delivered within an enticing gesture of openness, greeting, legibility. A similar scroll of 'shining yellow parchment' is indispensable within the ritual of the Tirsan feast, given to honour the father of the family who can boast 'thirty persons descended of his body alive together'. This scroll is the King's Charter, containing 'gift of revenew, and many privileges, exemptions and points of honour' (6o-2). The scroll thus simultaneously rewards and regulates generation, since breeding, it is suggested, is mainly a means to achieve financial security: thus, those who marry for 'alliance, or portion' (dowry) are 'almost indifferent ... of issue' (67). By conferring large amounts of money on the family as a whole, the scroll effectively limits what it celebrates, ingeniously controlling at the same time as glorifying population, and in the process offering freedoms to its beneficiaries which turn out, simultaneously, to be restrictions. Similarly, when the Father of Salomon's House conveys to the unnamed narrator of the New Atlantis the substance of the final portions of the text, he does so with his blessing and largess, giving 'leave to publish it' as well as 'about two thousand ducats, for a bounty' (83). If such plenitude is intended to signal the ripe finishedness and full presence of the text, then nevertheless we have already seen how the monologic purity of the Father's descriptions contains, as a precondition, a host of limitations, restrictions and prohibitions. As I have suggested, these serve not so much to conceal an 'inner' truth, as critics of the New Atlantis would have it, as to suggest unfinishedness, that there is more to know. From this perspective, a finished text would seem to be wholly dependent on its unfinishedness, perhaps offering a key to the question of why Rawley inscribes at the end of the New Atlantis '[THE REST WAS NOT PERFECTED]', even though, as Faulkner points out, Bacon must have considered it ready for publication to have translated it into Latin, the universal language (the language of the book), before his death (32I). ${ }^{36}$

Thus, in the context of the institutionalisation and systematised circulation of writing underlined here by the powerful ties between academy and state found in Bensalem, these examples 
show once more how openness, freedom from obligation, and textual originality remain inseparable from the forms of censorship, regulation and restraint that in fact produce them. The borders between freedom and prohibition, knowledge and censorship, inside and outside, are radically unstable within the space and vision of the institution, collapsing these supposed oppositions into more complex and indeterminate formations characterised by, for example, the non-self-identical doubleness, the uncanny twinning, of Europe/Bensalem. However, in relation to questions of the limitations placed on the production of knowledge within this academy, it is also suggested that, while such boundaries can never seem to be stabilised, their very indeterminacy and fluidity is precisely what sustains the project of such enlightenment. The masquerade of secrecy in Bensalem achieves this canny effect: no matter how far the frontiers of knowledge are pushed back, there's always more to know just over the threshold. As we have seen, then, it is the absence of limitations that limits what can become 'known', while the positioning of boundaries, particularly shifting and thus incessant ones, remains vital in the crossing or journey towards enlightened knowledge.

\section{Notes}

I Robert K. Faulkner, Francis Bacon and the Project of Progress (Maryland, Rowman and Littlefield, I993), p. 248.

2 Jerry Weinberger, 'Introduction' to Francis Bacon, New Atlantis and The Great Instauration, ed. Jerry Weinberger (Wheeling, Illinois, Harlan Davidson, I980, revised edn, I989), p. xxxii.

3 Richard Burt, Licensed by Authority: Ben Jonson and the Discourses of Censorship (Ithaca and London, Cornell University Press, I993).

4 Ibid., p. I5 2.

5 Robert Young, White Mythologies: Writing, History and the West (London, Routledge, I990), p. 89.

6 Burt, Licensed by Authority, pp. 152-3.

7 Jonathan Dollimore and Alan Sinfield, 'Foreword', in Jonathan Dollimore and Alan Sinfield (eds), Political Shakespeare: New Essays in Cultural Materialism (Manchester, Manchester University Press, I985).

8 Margot Heinemann, 'How Brecht read Shakespeare', in Political Shakespeare, p. 203. 
9 Robert Young, "The politics of "the politics of literary theory", OLR, Io (I988) I32.

Io Walter Cohen, 'Political criticism of Shakespeare', in Jean Howard and Marion O' Connor (eds), Shakespeare Reproduced: The Text in History and Ideology (London, Methuen, I987), p. 20.

I I See Pierre Bourdieu, 'Censorship and the imposition of form', in Language and Symbolic Power, ed. and intro. John B. Thompson, trans. Gino Raymond and Matthew Adamson (Oxford, Basil Blackwell, I99I), p. I37.

I2 Burt, Licensed by Authority, p. I I.

I3 Ibid., p. I3.

I4 Richard Dutton, Mastering the Revels: The Regulation and Censorship of English Renaissance Drama (London, Macmillan, I99I), p. 248.

I5 Annabel Patterson, Censorship and Interpretation: The Conditions of Writing and Reading in Early Modern England (Madison, Wisconsin, University of Wisconsin Press, 1984), p. 4.

I6 Janet Clare, Art Made Tongue-Tied by Authority: Elizabethan and Jacobean Censorship (Manchester, Manchester University Press, I990); Kevin Sharpe, Criticism and Compliment: The Politics of Literature in the England of Charles I (Cambridge, Cambridge University Press, 1987); Steven Mullaney, The Place of the Stage: License, Play and Power in Renaissance England (Chicago, University of Chicago Press, i987).

I 7 Geoffrey Bennington, Lyotard: Writing the Event (Manchester, Manchester University Press, I988), p. I I5.

I8 Francis Bacon, New Atlantis and The Great Instauration, ed. Jerry Weinberger (Wheeling, Illinois, Harlan Davidson, I980, revised edn, I989). All further references will be given in the main body of the text.

I9 B. H. G. Wormald, Francis Bacon: History, Politics and Science, I56I-I626 (Cambridge, Cambridge University Press, 1993), p. 235.

20 Faulkner, Francis Bacon, p. 248.

2 I Weinberger, 'Introduction', p. xxxii.

22 Faulkner, Francis Bacon, p. 235.

23 Ibid., p. 246.

24 Sigmund Freud, 'The Uncanny', The Penguin Freud Library Volume I4: Art and Literature, ed. Albert Dickson (London, Penguin, I985), p. 345.

25 Weinberger, 'Introduction', p. xxxii.

26 Faulkner, for example, notes that the officer of Salomon's House 'waxes enthusiastic and didactic about Bensalem's salvation from infidelity, through the "apostolical and miraculous evangelism of St. Bartholomew." A messenger interrupts him when he pauses. When he returns, the topic is the marvel of Bensalem as unknown knower, and our governor-priest smiles at the suggestion that Bensalem benefits from supernatural spirits. Does someone listen and direct from behind the scenes?' $\left(245^{-6}\right)$. Later on, Faulkner remarks that 'the priest is interrupted by a messenger just after 
he waxes evangelical, and is called away; we are later told of devices for transmitting sounds in pipes and lines' (249).

27 Lyotard writes: 'Scientific knowledge cannot know and make known that it is the true knowledge without resorting to the other, narrative, kind of knowledge, which from its point of view is no knowledge at all. Without such recourse it would be in the position of presupposing its own validity and would be stooping to what it condemns: begging the question, proceeding on prejudice' (The Postmodern Condition (Manchester, Manchester University Press, 1984), p. 29). Yet it is in relation to this passage that Bennington discusses Lyotard's concept of a shift from premodern to modern forms of scientific legitimation which allow for consensual discussion among experts leading to improvements in the rules for speaking the truth, 'projected into a future under the sign of progress' (Bennington, Lyotard, p. I I5).

28 Weinberger, 'Introduction', p. xvi.

29 See Paul de Man, 'The resistance to theory', in The Resistance to Theory (Minneapolis, University of Minnesota Press, I986), pp. Io-I I.

30 Christopher Pye, 'The sovereign, the theater, and the kingdome of darknesse: Hobbes and the spectacle of power', in Stephen Greenblatt (ed.), Representing the English Renaissance (California, University of California Press, I988), p. 295.

3I Pye's article touches upon the solar imagery of early modern power, but for a fuller discussion of this in relation to the literature of James I's accession, see Simon Wortham, 'Sovereign counterfeits: the trial of the pyx', Renaissance Quarterly, 49.2 (Summer i996) 334-59.

32 Faulkner, Francis Bacon, p. 237.

33 Ibid., p. 243.

34 Ibid., p. 239.

35 Ibid., p. 237.

36 The New Atlantis is indeed open-ended and, as it were, unfinished at both ends, since the text commences by joining the Europeans in mid-voyage. Kate Aughterson, in "The waking vision": reference in the New Atlantis', Renaissance Quarterly, 45.I (Spring I992) I I9-39, argues that the opening passage, beginning, 'We sailed from Peru, (where we had continued by the space of one whole year)', comprises 'simple vocabulary', 'accurate geographical directions' and a straightforward fit between syntactic and temporal sequence, which epitomises an 'apparently closed system of determining referents' (I22). Aughterson thereby suggests that, apparently, 'no reference is unfixed or floating' (I22), yet the irony of this metaphorical representation of reference as 'unfloating' is that the opening sequence of the New Atlantis is about a voyage at sea! Moreover, the description of the Europeans as having 'continued' awhile in Peru carries the sense of ongoingness, impermanence, flux. Thus, Aughterson concludes that 'metaphoric "open-endedness"' arises out of the seemingly 'closed system' (I22): to some extent, this parallels my argument about the inseparable relation of censorship and freedom or enlightenment in the New Atlantis. 